\title{
Society for Endocrinology Competency Framework for Adult Endocrine Nursing: 2nd edition
}

\author{
Veronica Kieffer, Kate Davies', Christine Gibson' ${ }^{2}$, Morag Middleton ${ }^{3}$, \\ Jean Munday ${ }^{4}$, Shashana Shalet ${ }^{5}$, Lisa Shepherd ${ }^{6}$ and Phillip Yeoh ${ }^{7}$
}

University Hospitals of Leicester NHS Trust, Department of Diabetes and Endocrinology, Leicester Royal Infirmary, Leicester, LE1 5WW, UK

${ }^{1}$ Great Ormond Street Hospital for Children NHS Trust, London, UK

${ }^{2}$ Central Manchester University Hospitals NHS Foundation Trust, Manchester, UK

${ }^{3} \mathrm{NHS}$ Grampian, Aberdeen, UK

${ }^{4}$ Portsmouth Hospitals NHS Trust, Portsmouth, UK

${ }^{5}$ Salford Royal Hospitals Foundation Trust, Salford, UK

${ }^{6}$ Heart of England NHS Foundation Trust, Birmingham, UK

${ }^{7}$ The London Clinic, London, UK

Correspondence

should be addressed

to $\mathrm{V}$ Kieffer

Email

nikki.kieffer@uhl-tr.nhs.uk

\begin{abstract}
This competency framework was developed by a working group of endocrine specialist nurses with the support of the Society for Endocrinology to enhance the clinical care that adults with an endocrine disorder receive. Nurses should be able to demonstrate that they are functioning at an optimal level in order for patients to receive appropriate care.

By formulating a competency framework from which an adult endocrine nurse specialist can work, it is envisaged that their development as professional practitioners can be enhanced. This is the second edition of the Competency Framework for Adult Endocrine Nursing. It introduces four new competencies on benign adrenal tumours, hypo- and hyperparathyroidism, osteoporosis and polycystic ovary syndrome. The authors and the Society for Endocrinology welcome constructive feedback on the document, both nationally and internationally, in anticipation that further developments and ideas can be incorporated into future versions.
\end{abstract}
Key Words
- nursing
- endocrinology
- competency framework

\section{Introduction}

Competence has been defined as 'The state of having the knowledge, judgement, skills, energy, experience and motivation required to respond adequately to the demands of one's professional responsibilities' (1). It is also defined as 'being able to demonstrate that the knowledge, values and skills learned can be integrated into practice' (2).

Adult endocrine nursing is highly specialised and, in recent years, nurses have expanded their roles according to local need. The Society for Endocrinology Nurse Committee believes that professional advice and support are required for nurses developing their roles in this dynamic and rapidly advancing field (3).

In 2013, the first edition of the Society for Endocrinology Competency Framework for Adult Endocrine Nursing was published (4). Subsequently, four new competencies - benign adrenal tumours, hypo- and hyperparathyroidism, osteoporosis and polycystic ovary syndrome - have been added to this second edition. These competencies build on the work already undertaken by our paediatric endocrine nurse colleagues.

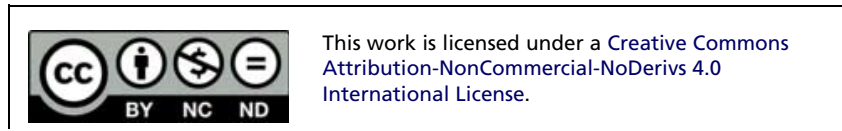


However, we recognise that adult endocrine nurse specialists have a more disparate range of roles. Some nurses may care for a whole range of endocrine disorders, whereas others may concentrate on one specific disease area. Therefore nurses, and their clinical managers, will need to select the competencies which are particular to their role.

In addition, it is recognised that some endocrine nurses may be caring for patients in situations not covered in this document. It is accepted that this is due to the way many posts were initiated to deal with a particular local requirement, and it is hoped that these competencies will help those individual nurses to develop competencies relevant to their own roles. In the future, additional competencies will be developed as the need for them is identified.

Benner's 'Novice to Expert' concept has been used and adapted as the basis for these competencies $(5,6,7)$. As a general rule, we would expect nurses new to the specialty to have reached a competent level within 6 months.

An endocrine nurse functioning at 'expert' level is likely to have had some years of experience in the specialty and be working autonomously. We recognise that some nurses could be 'experts' in a particular disease area whilst only achieving a 'competent' level in another area. Not all competencies will apply to all endocrine specialist nurses.

The competency framework has been developed in this context, as well as taking into account other professional and political factors such as:

- The need for the development of UK-wide standards in adult endocrine nursing.

- The need for professional accreditation of skills and knowledge in practice.

- The increased focus on work-based and lifelong learning plus supervision.

- Increasing patient and user expectations.

- The need for leadership in specialist nursing.

- National service frameworks, clinical governance and service modernisation.

\section{The adult endocrine nurse specialist role}

The adult endocrine nurse specialist should be a nurse registered with the Nursing and Midwifery Council (NMC) and holding a first degree. It is envisaged that the endocrine nurse specialist acting in the 'expert' role should hold, or be actively working towards, a Masters

http://www.endocrineconnections.org DOI: 10.1530/EC-14-0134 (c) 2015 Society for Endocrinology Published by Bioscientifica Ltd degree. An 'expert' will need to be an Independent Nurse Prescriber to be able to work autonomously at this level of clinical responsibility.

It is hoped that this competency framework will help endocrine nurses to identify their current level of practice and to plan their career in a more structured way by identifying their personal education and development needs.

Progression through the levels will be different for each nurse, depending on context, level of skill, performance appraisal and individual objectives. The endocrine nurse specialist may achieve 'expert' status, in those competencies relevant to them, after $\sim 5$ years in post.

Nurses should always be working to advance their practice. In the early 1990s, the UK Central Council for Nursing, Midwifery and Health Visiting - now the Nursing and Midwifery Council (NMC) - developed a Code of Conduct (8) which clearly describes how all nurses, midwives and health visitors must endeavour always to achieve, maintain and develop knowledge, skills and competence, and this was echoed in 2008 (9). It has been acknowledged that nurses are increasingly extending their roles and expanding their scope of practice beyond initial registration (10).

\section{How to use the framework}

The framework focuses on knowledge, skills and interventions that are specific to nurses working as adult endocrine nurses. Although the intention is for this framework to have a stand-alone function, it should be used in conjunction with other frameworks that focus on core skills and competencies for all qualified nurses and in conjunction with local and national guidelines.

\section{Benefits of the framework}

The competency framework provides benefits for nurses, their employers, patients and the public.

Nurses benefit because it helps to:

- Deliver consistently high standards of care.

- Identify the level of practice and plan a career in a more structured way.

- Pinpoint personal educational and developmental needs.

- Realise potential more effectively.

- Seize opportunities to influence the direction of nursing. 
Employers benefit because it provides:

- A model to ensure consistently high standards of care.

- Clearer insights into the expertise and competence of staff; for example, in assessment of risk management.

- Assistance in organisational planning.

Patients and the public benefit because it makes it possible to deliver:

- Consistently high standards of patient care.

- Increased effectiveness of service provision.

- Improved access and choice for care provision.

It is envisaged that this document will be a useful tool for:

- Supporting job descriptions and pay reviews/negotiations by detailing targets in accordance with local and national guidelines and policies.

- Assessing clinical competence at differing levels.

- Developing personal goals and objectives.

- Performance appraisal.

\section{Specialist competencies}

The adult endocrine nurse specialist competency framework is presented in the following tables:

Competency 1: Acromegaly.

Competency 2: Benign adrenal tumours.

Competency 3: Cushing's syndrome.

Competency 4: Endocrine dynamic function testing.

Competency 5: Growth hormone deficiency.

Competency 6: Hypo- and hyperparathyroidism.

Competency 7: Hypogonadism.

Competency 8: Hypopituitarism.

Competency 9: Osteoporosis.

Competency 10: Polycystic ovary syndrome.

Competency 11: Steroid replacement therapy for disorders of the pituitary and adrenal glands.

Competency 12: Thyroid disease.

Competency 13: Transition.
This work is licensed under a Creative Commons Attribution-NonCommercial-NoDerivs 4.0 International License. 

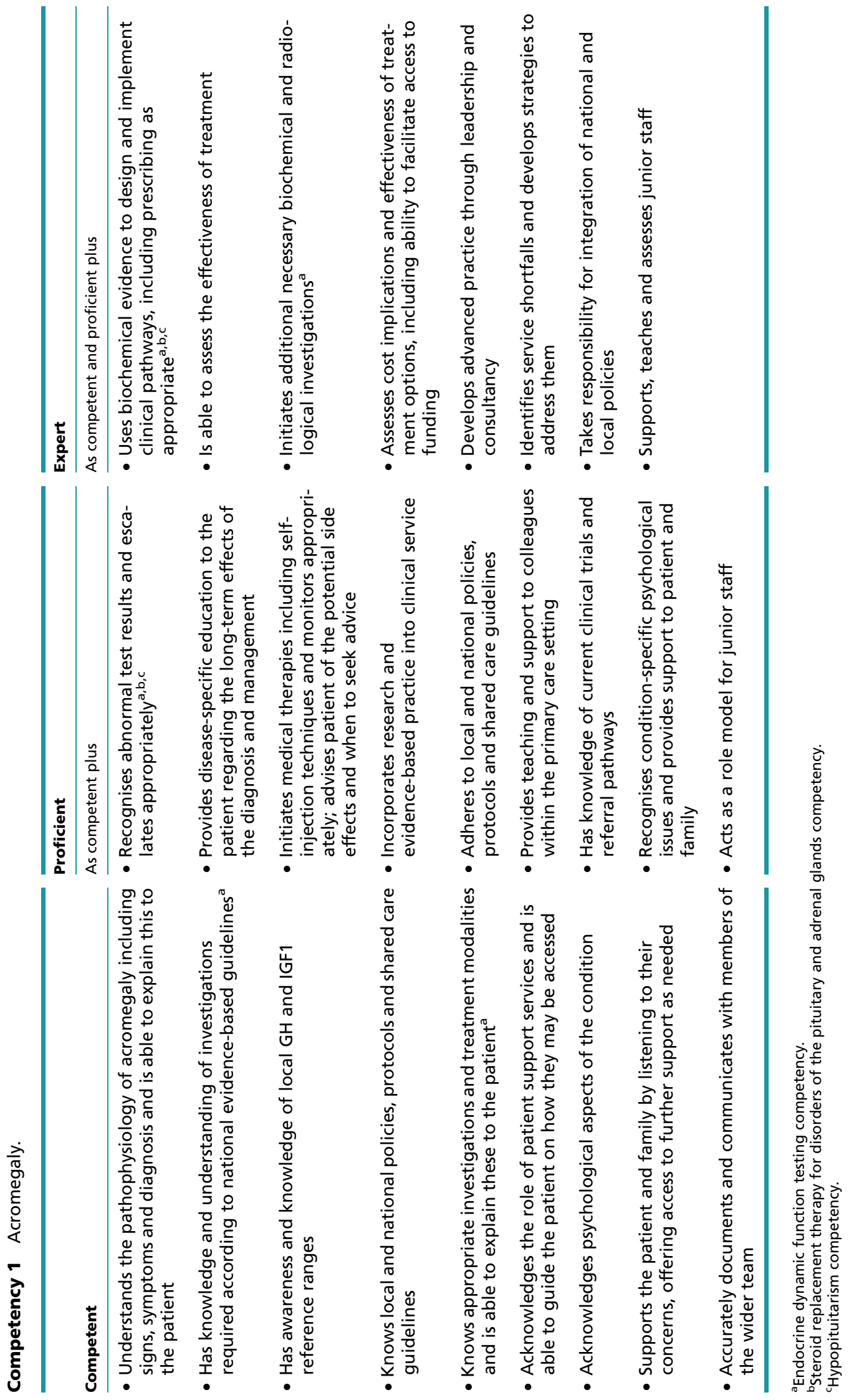

$\begin{array}{lr}\text { http://www.endocrineconnections.org } & \text { ○ } 2015 \text { Society for Endocrinology } \\ \text { DOI: } 10.1530 / \text { EC-14-0134 } & \text { Published by Bioscientifica Ltd }\end{array}$ 

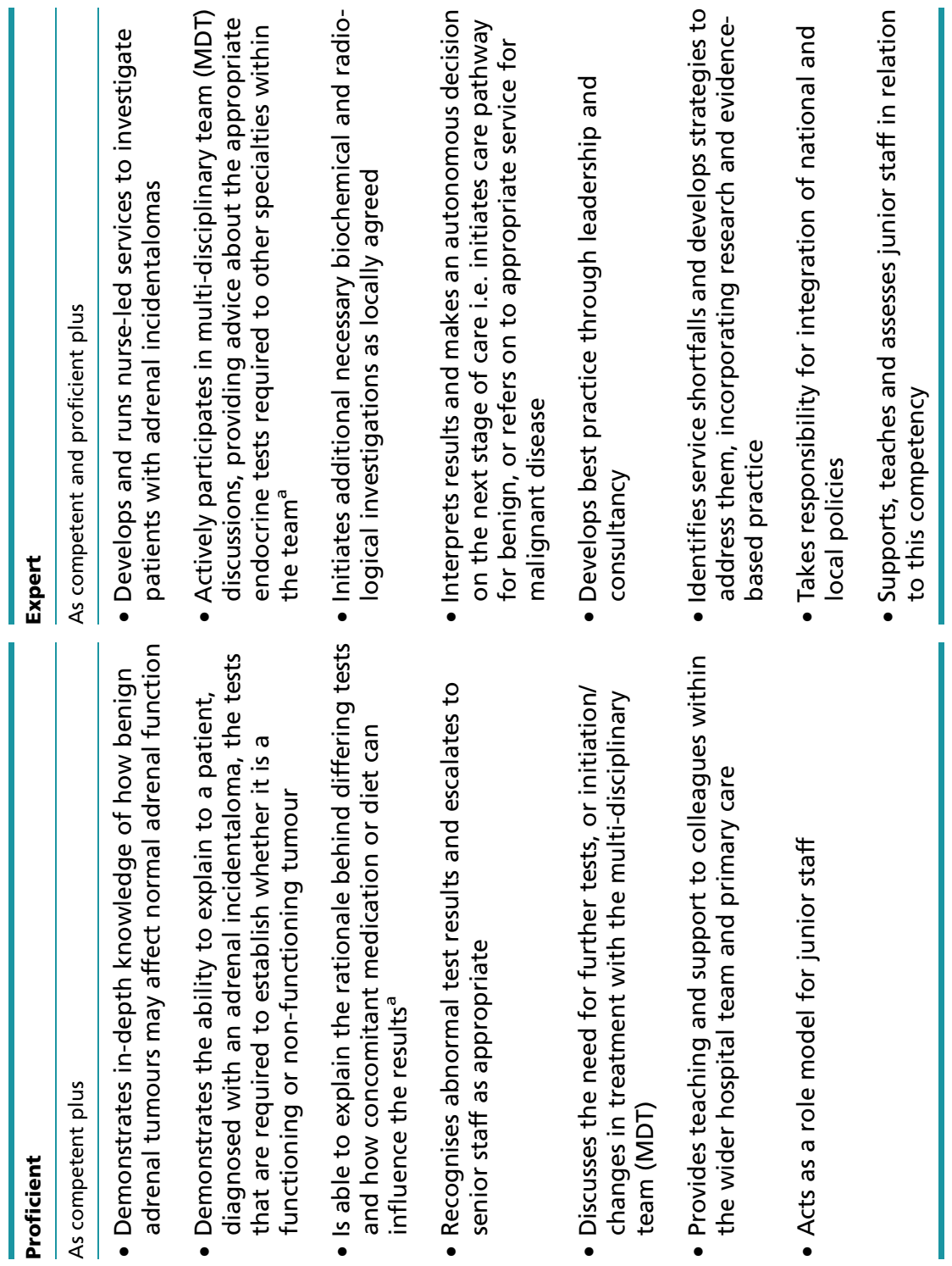

동
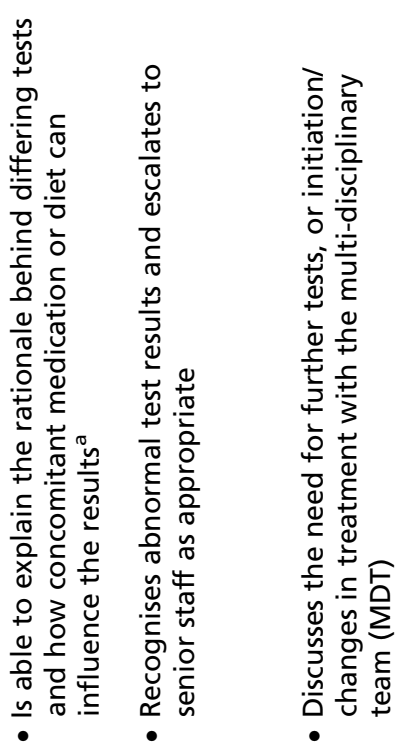

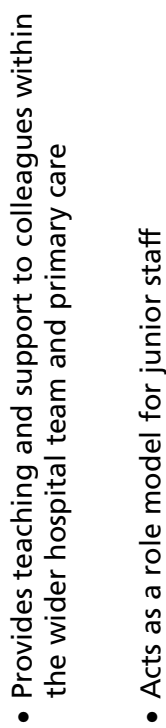
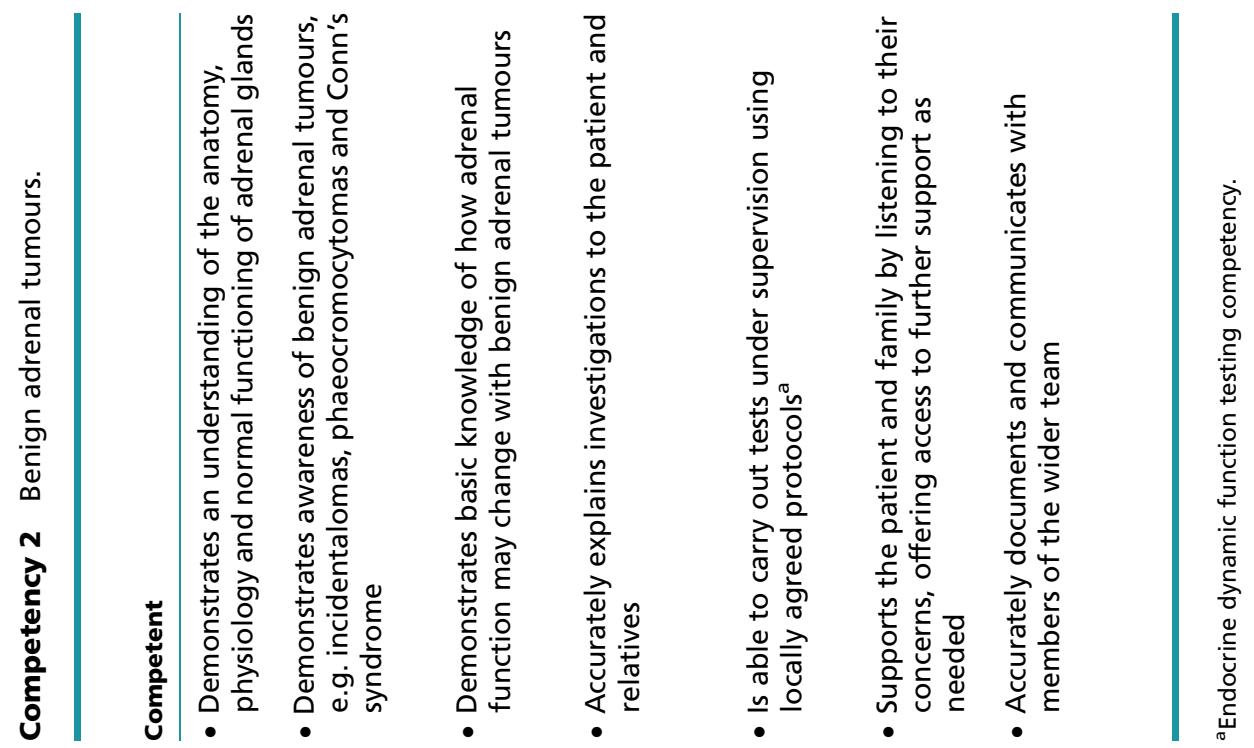

http://www.endocrineconnections.org DOI: 10.1530/EC-14-0134
๑) 2015 Society for Endocrinology Published by Bioscientifica Ltd (C) $\$=\begin{aligned} & \text { This work is licensed under a Creative Commons } \\ & \text { Attribution-NonCommercial-NoDerivs } 4.0\end{aligned}$ International License. 

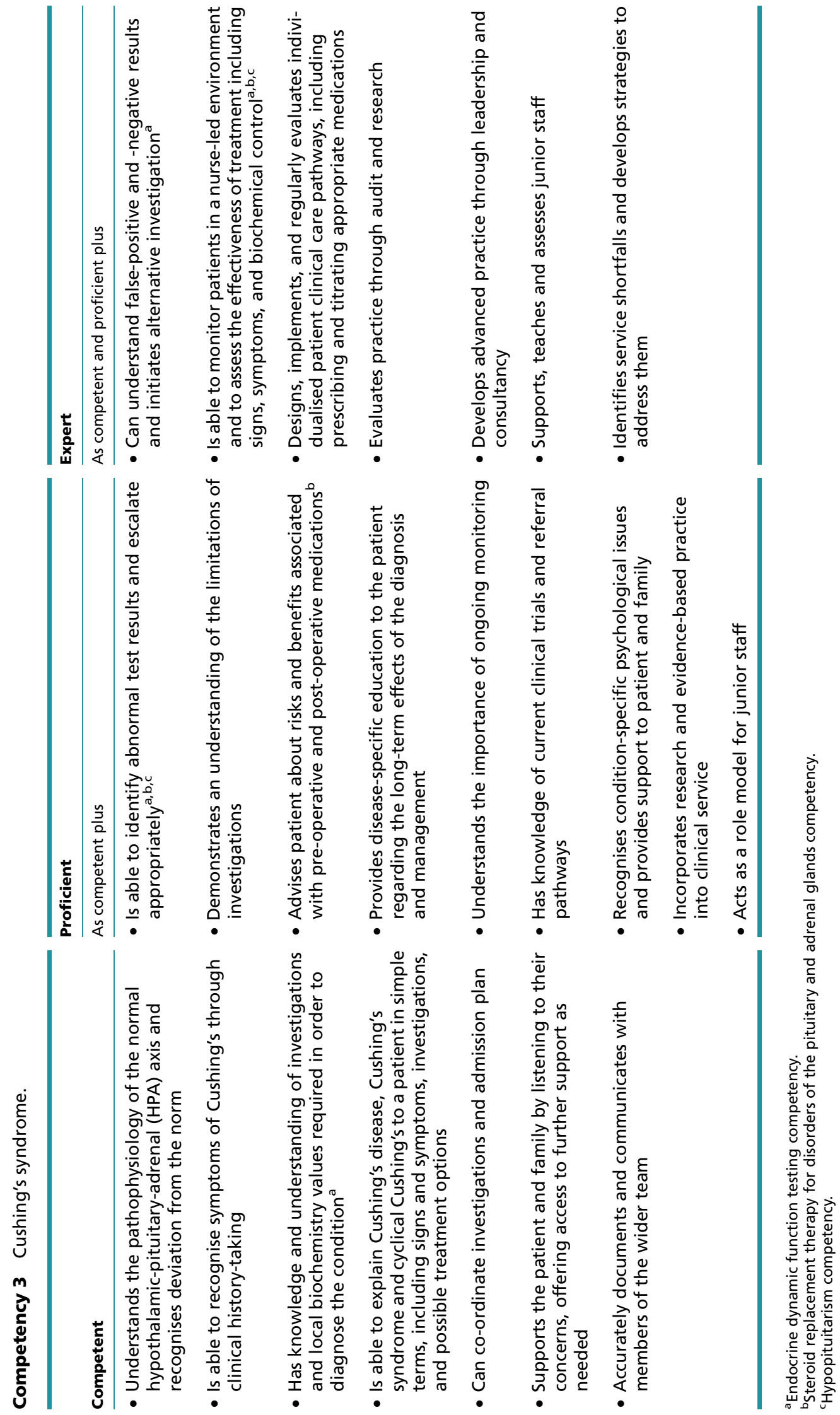

http://www.endocrineconnections.org DOI: 10.1530/EC-14-0134
๑) 2015 Society for Endocrinology Published by Bioscientifica Ltd CC) $=\begin{aligned} & \text { This work is licensed under a Creative Commons } \\ & \text { Attribution-NonCommercial-NoDerivs } 4.0\end{aligned}$ Attribution-NonComm
International License. 

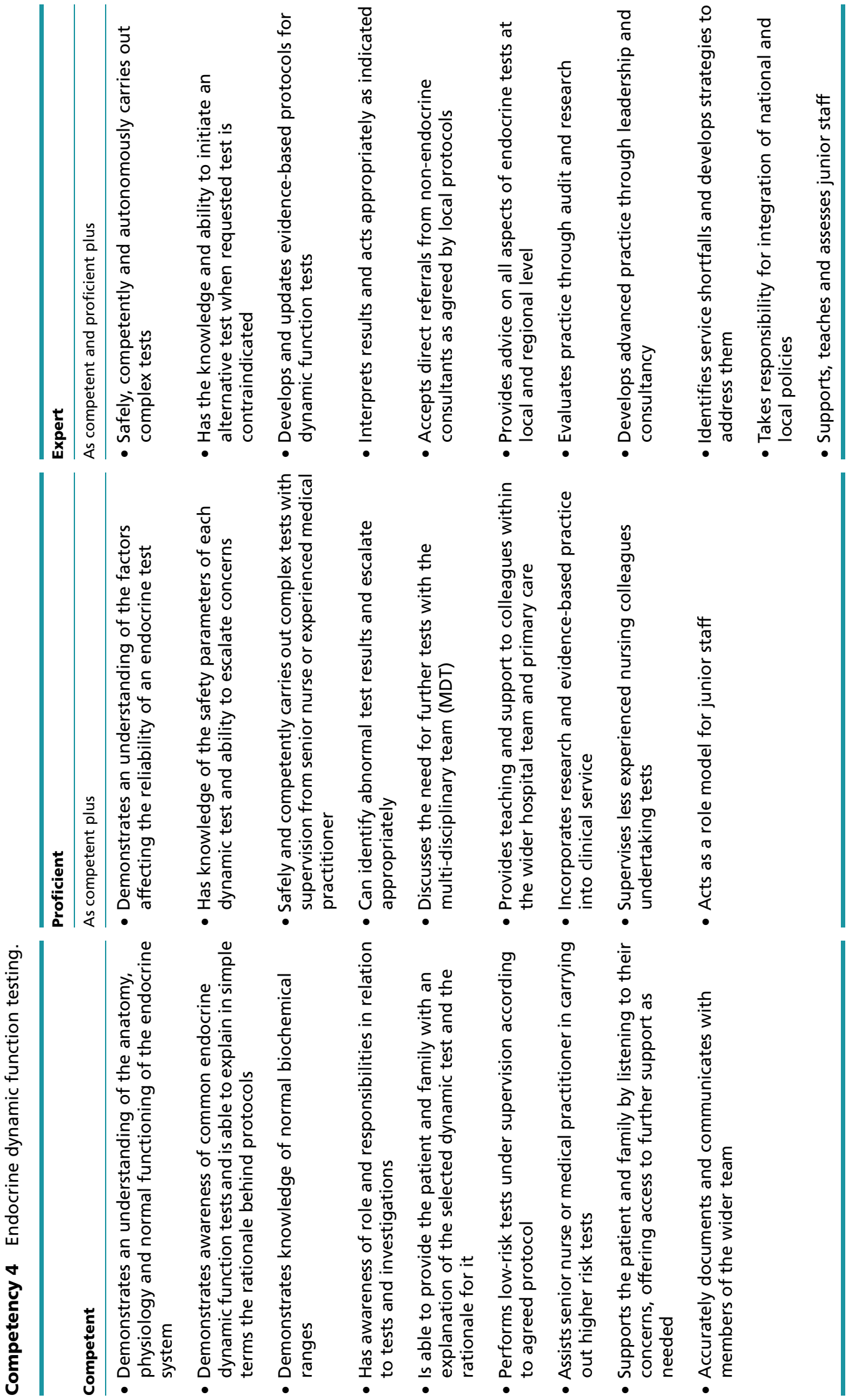

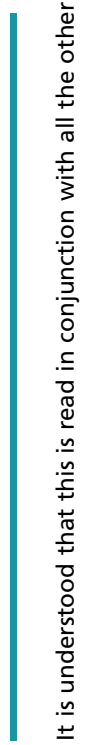

http://www.endocrineconnections.org DOI: 10.1530/EC-14-0134
(๑) 2015 Society for Endocrinology Published by Bioscientifica Ltd CC. This work is licensed under a Creative Commons Attribution-NonComm 

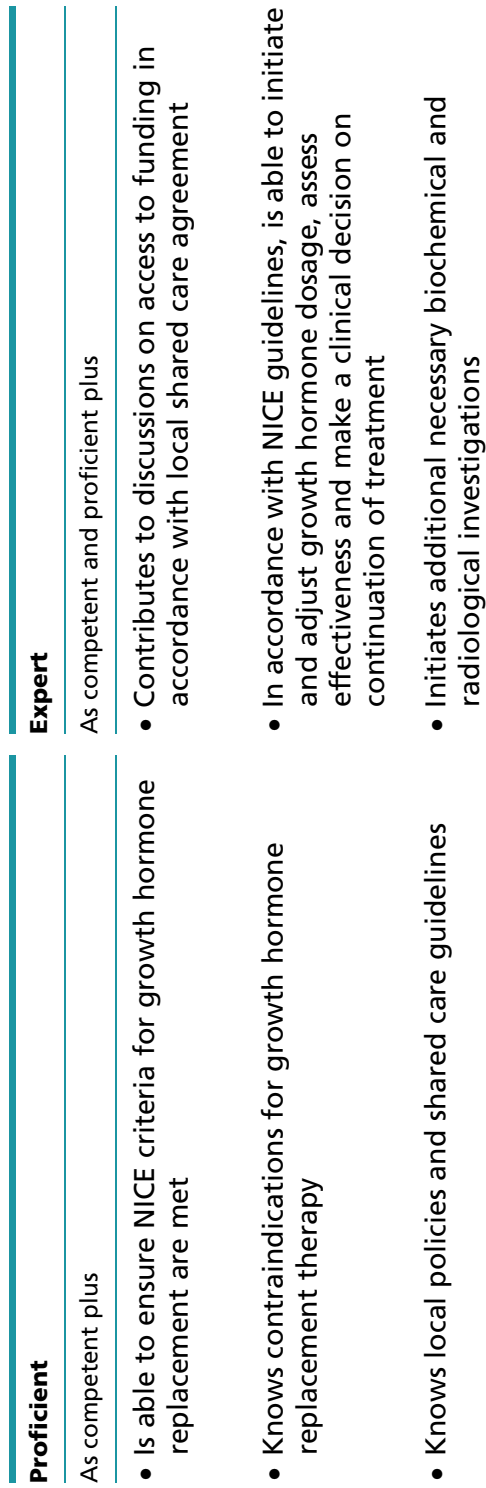
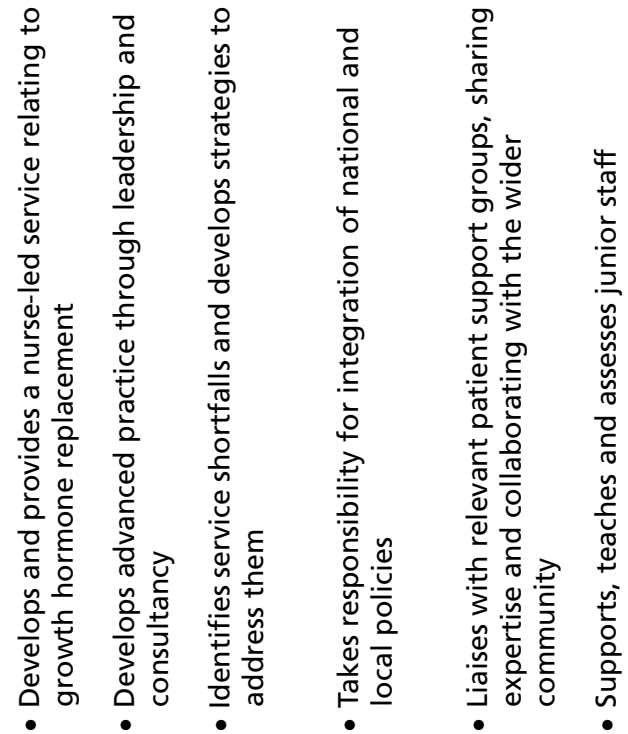
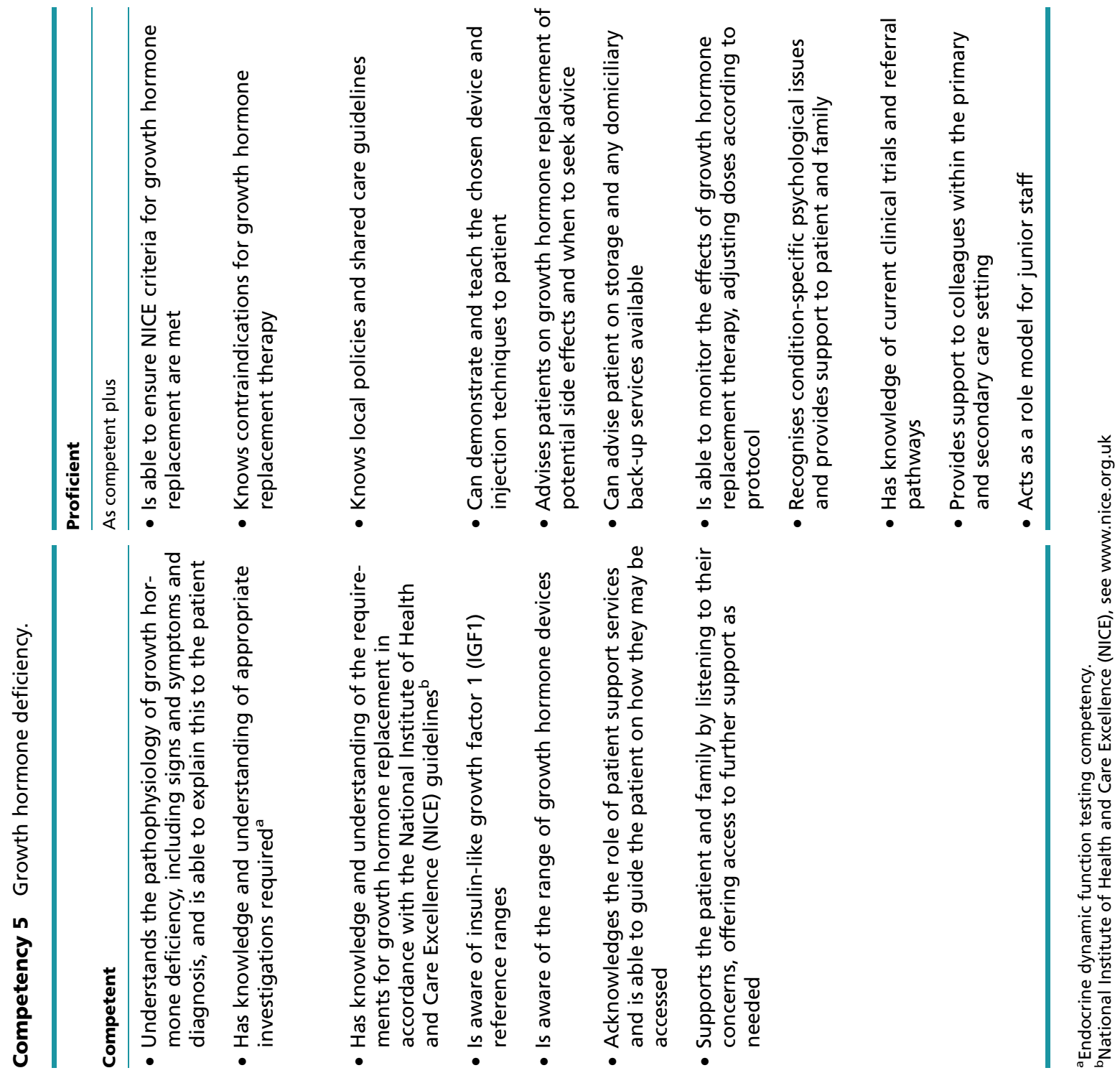

http://www.endocrineconnections.org DOI: 10.1530/EC-14-0134 (c) 2015 Society for Endocrinology Published by Bioscientifica Ltd (C) \$ @ @ 


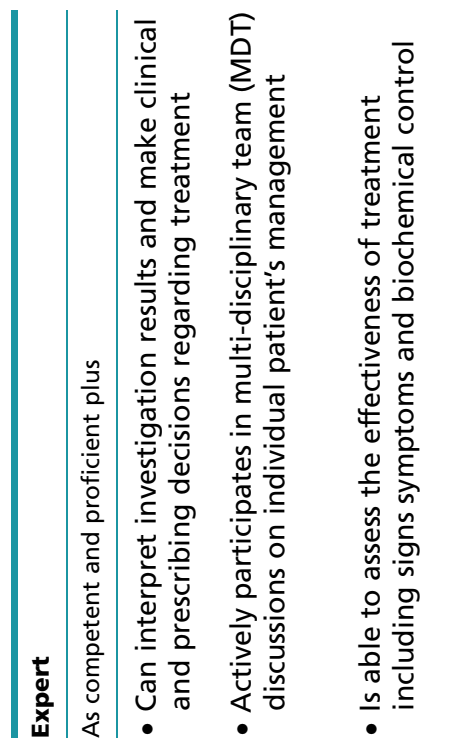

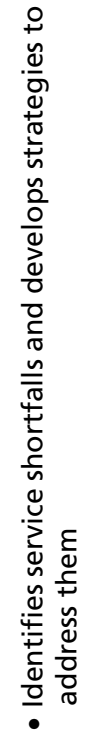
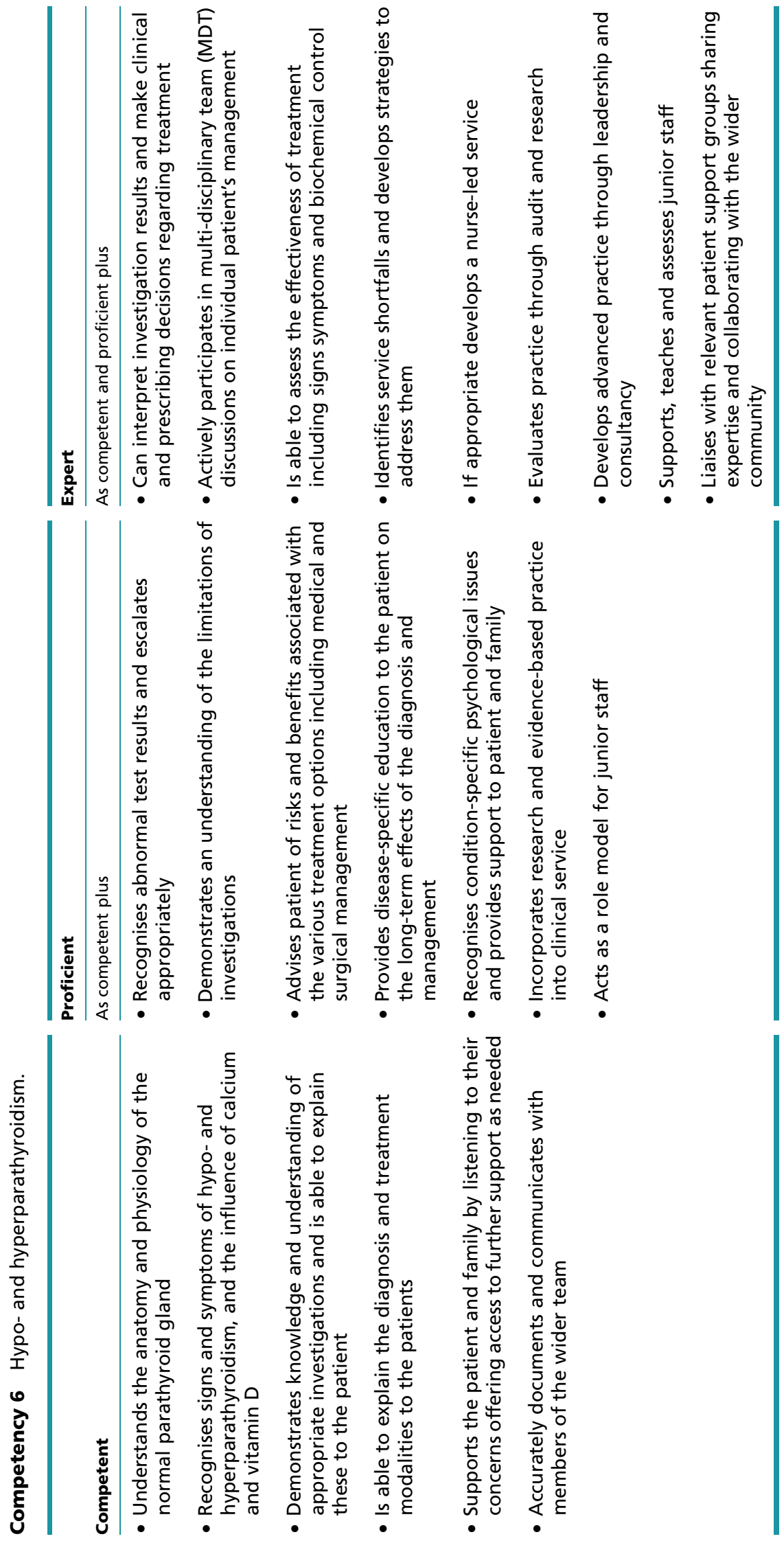

http://www.endocrineconnections.org DOI: 10.1530/EC-14-0134
๑ 2015 Society for Endocrinology Published by Bioscientifica Ltd 

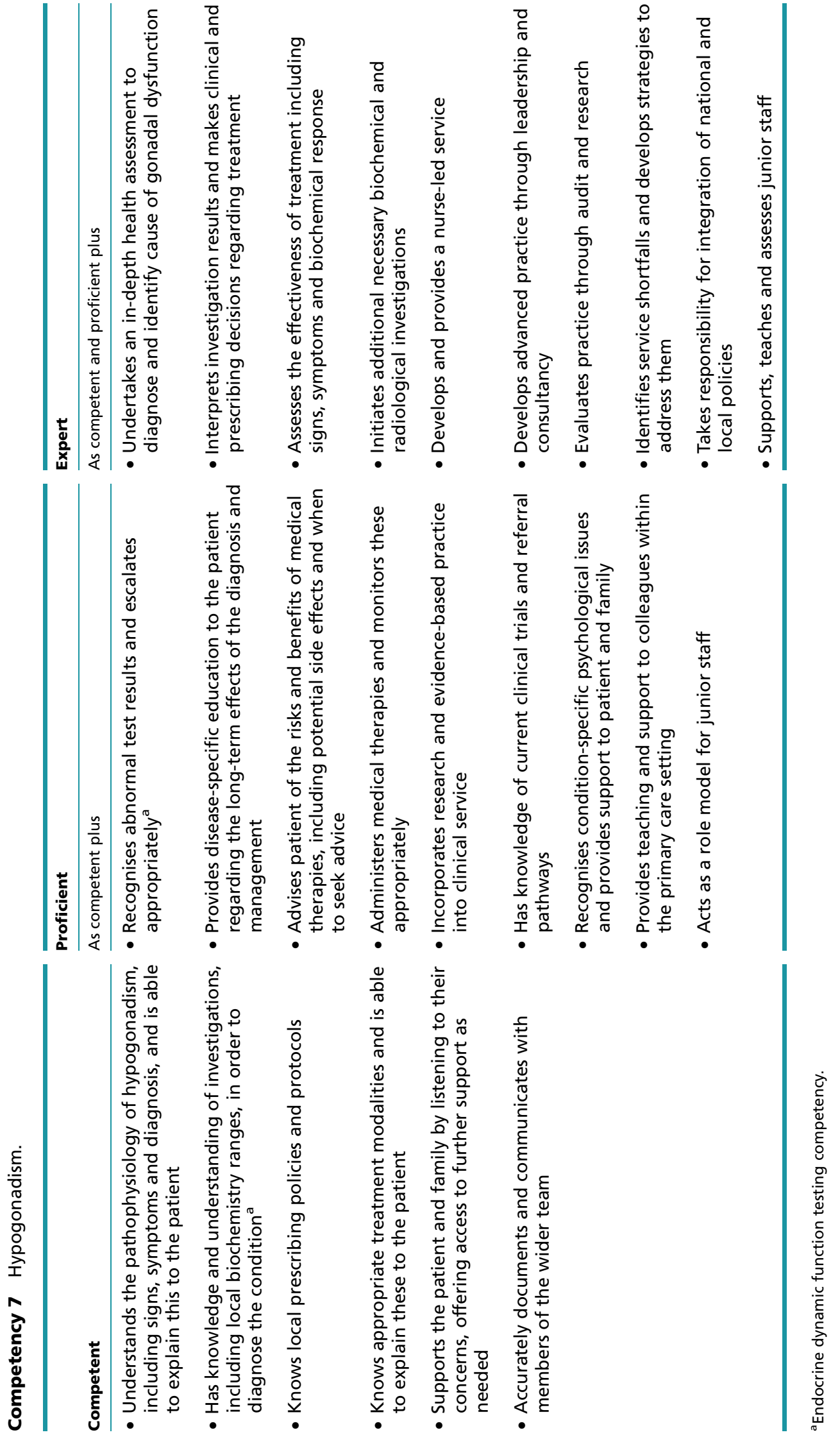

http://www.endocrineconnections.org DOI: 10.1530/EC-14-0134
() 2015 Society for Endocrinology Published by Bioscientifica Ltd

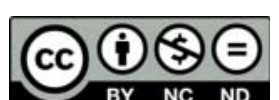

This work is licensed under a Creative Commons Attribution-NonCommercial-NoDerivs 4.0 International License. 

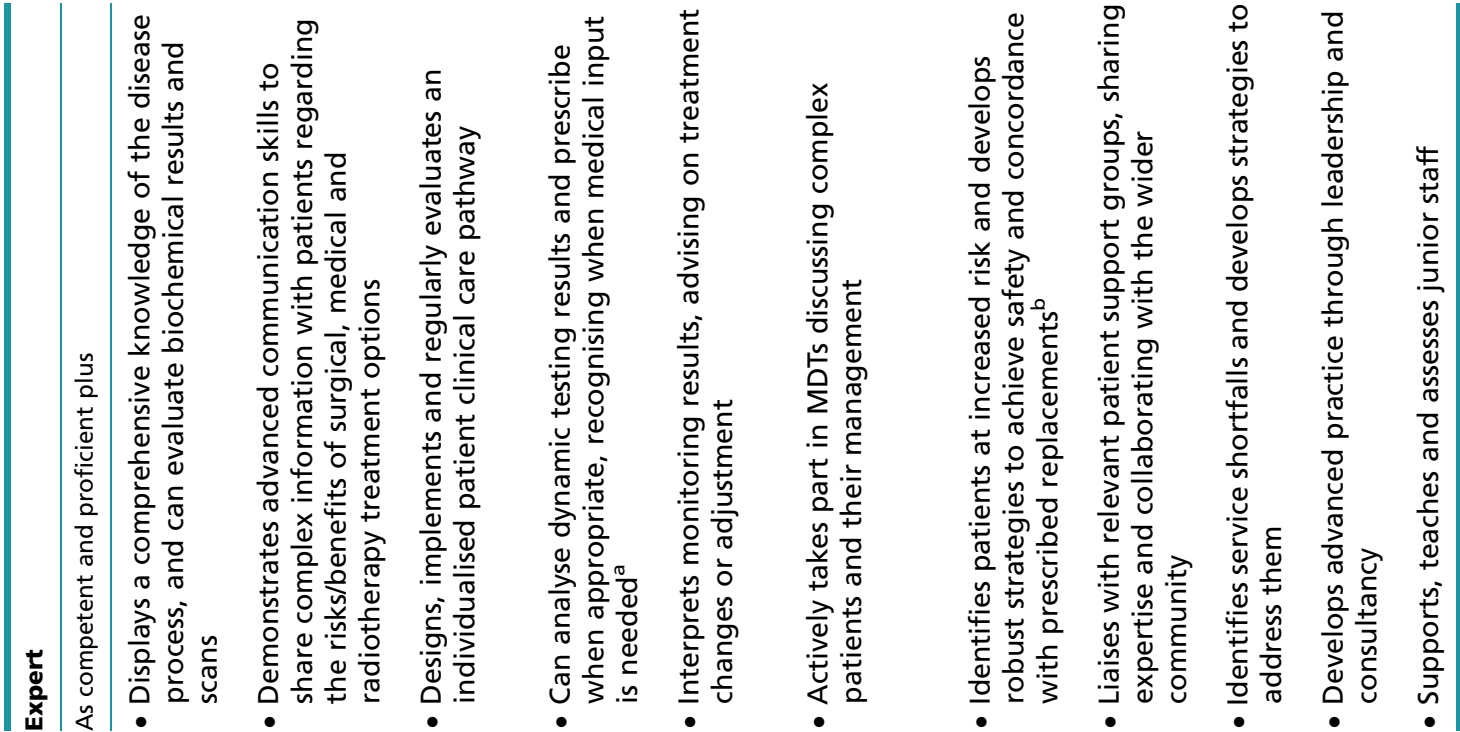

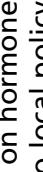

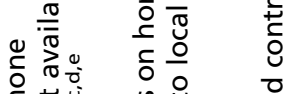

\section{$\check{c}$}

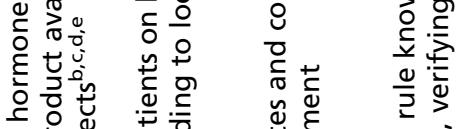

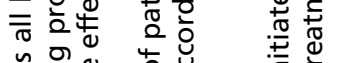

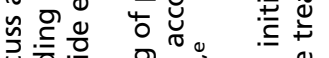

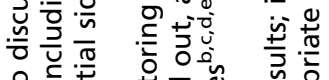

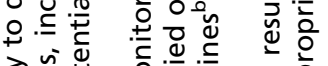

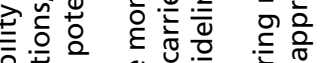

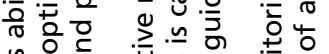

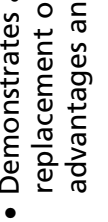

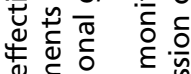

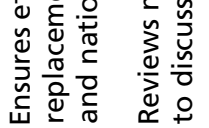

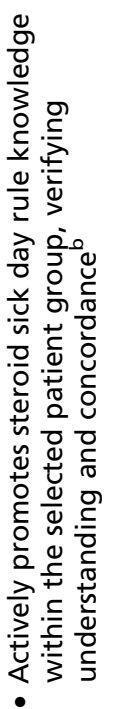

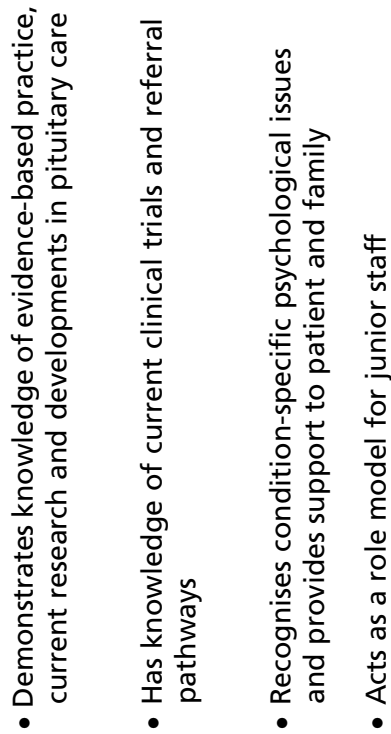

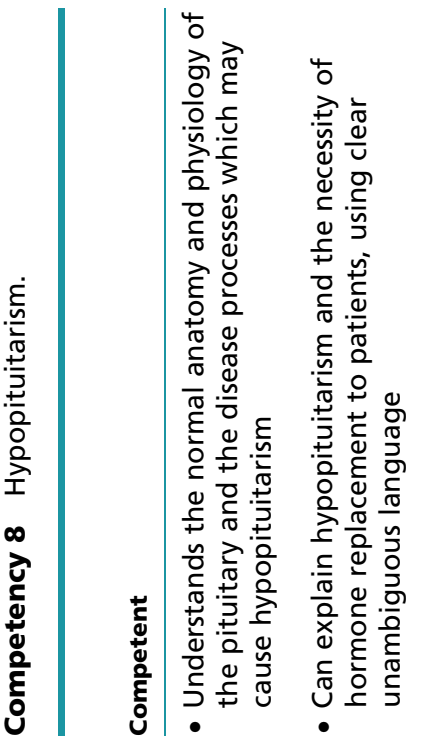

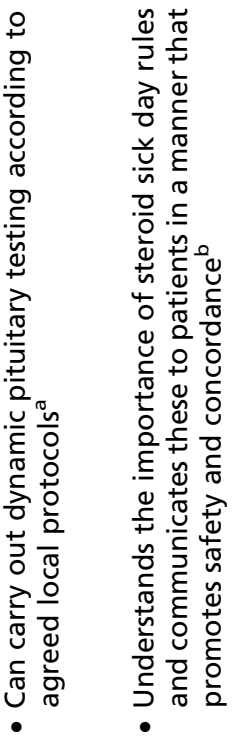
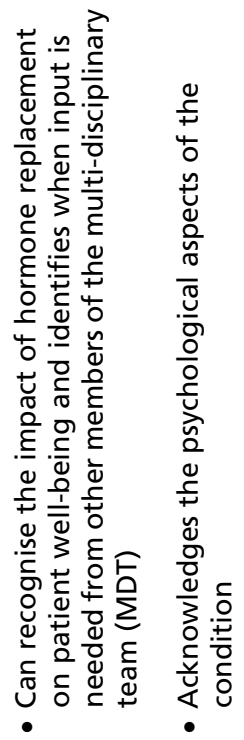

产
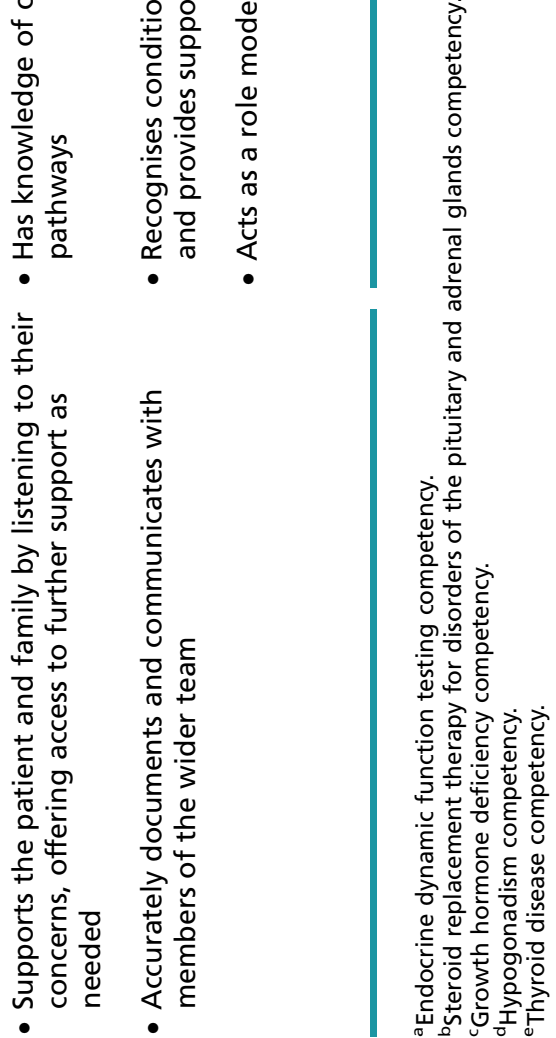

http://www.endocrineconnections.org

() 2015 Society for Endocrinology Published by Bioscientifica Ltd 

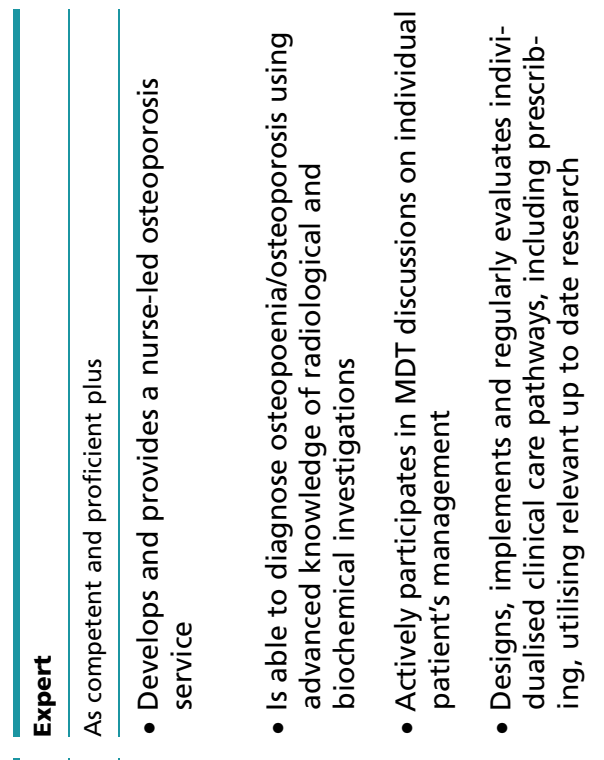
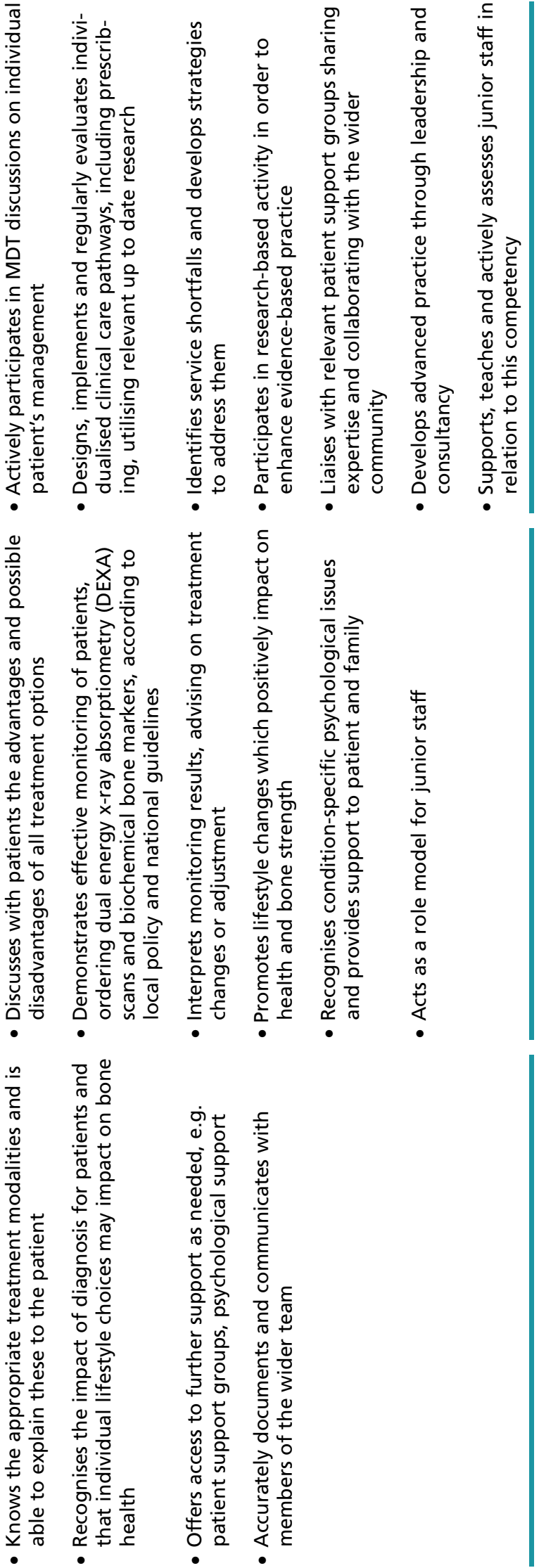

http://www.endocrineconnections.org DOI: 10.1530/EC-14-0134
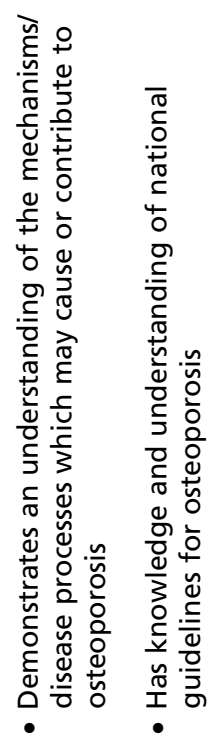

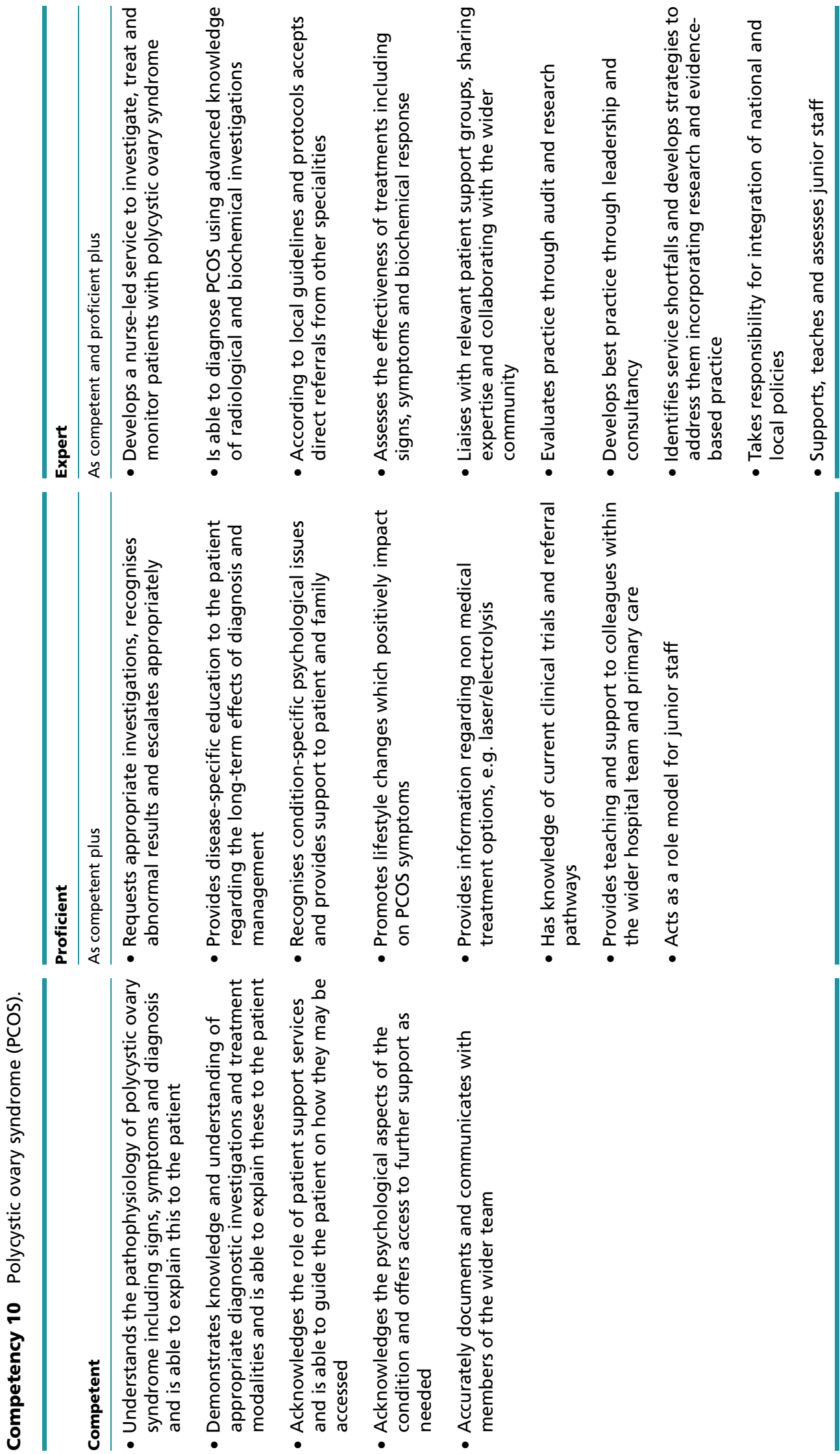

http://www.endocrineconnections.org DOI: 10.1530/EC-14-0134
(C) 2015 Society for Endocrinology Published by Bioscientifica Ltd

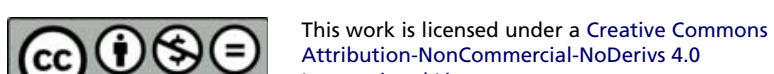
International License. 

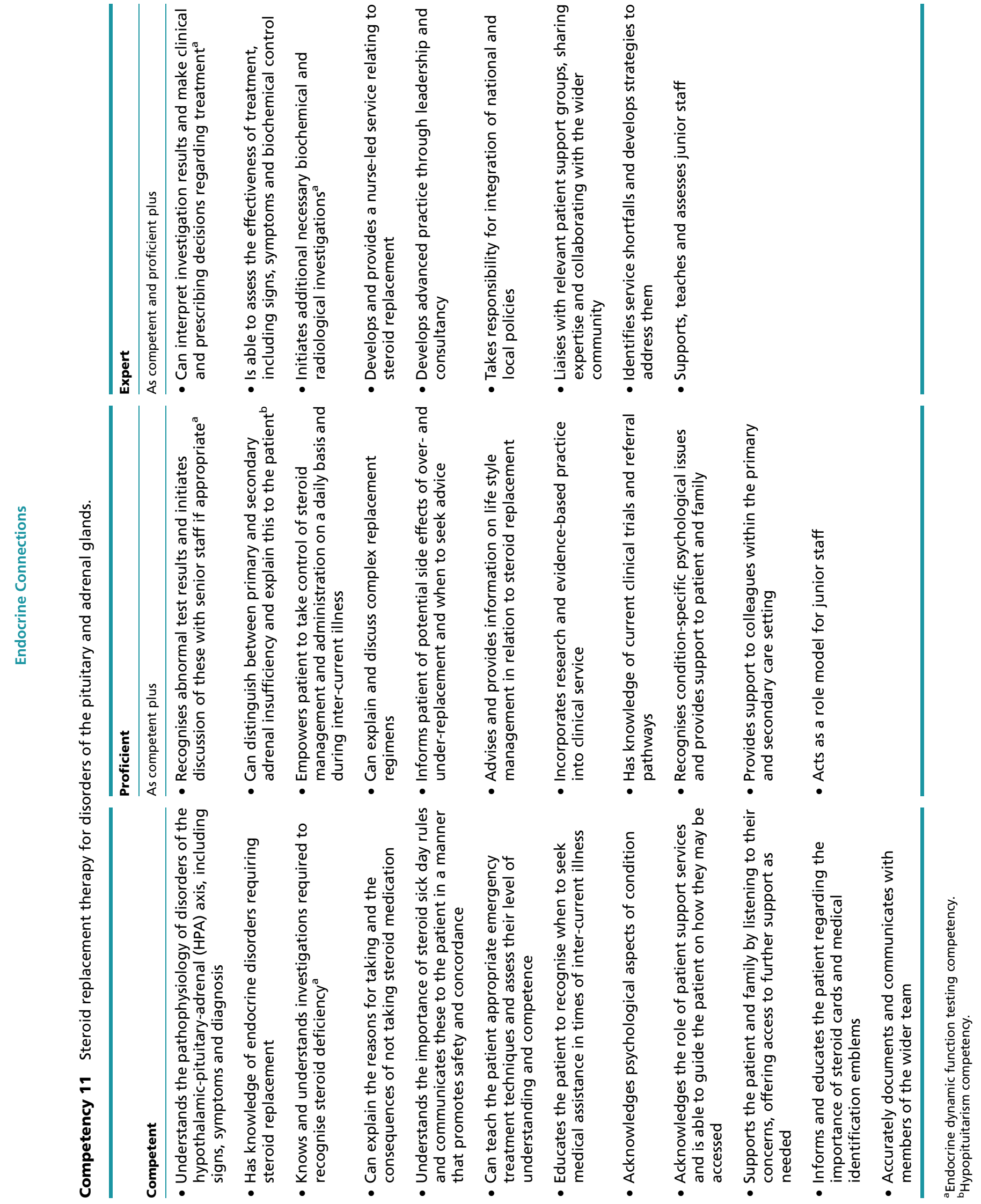

$$
\begin{array}{lr}
\text { http://www.endocrineconnections.org } & \odot 2015 \text { Society for Endocrinology } \\
\text { DOI: } 10.1530 / E C-14-0134 & \text { Published by Bioscientifica Ltd }
\end{array}
$$



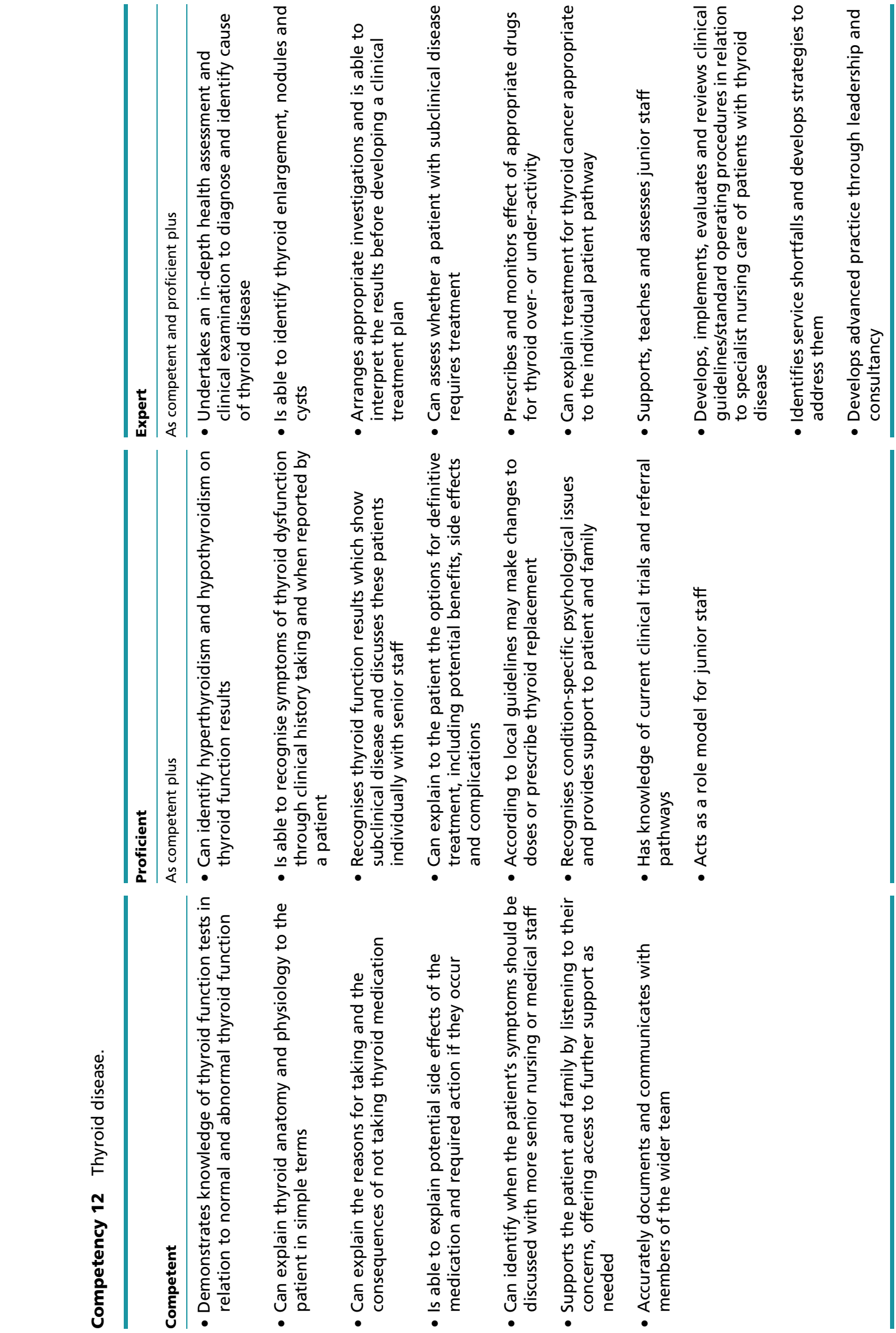

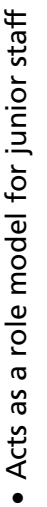

http://www.endocrineconnections.org DOI: 10.1530/EC-14-0134
๑ 2015 Society for Endocrinology Published by Bioscientifica Ltd (c) $\$\left(\begin{array}{l}\text { This work is licensed under a Creative Commons } \\ \text { Attribution-NonCommercial-NoDerivs } 4.0\end{array}\right.$ 

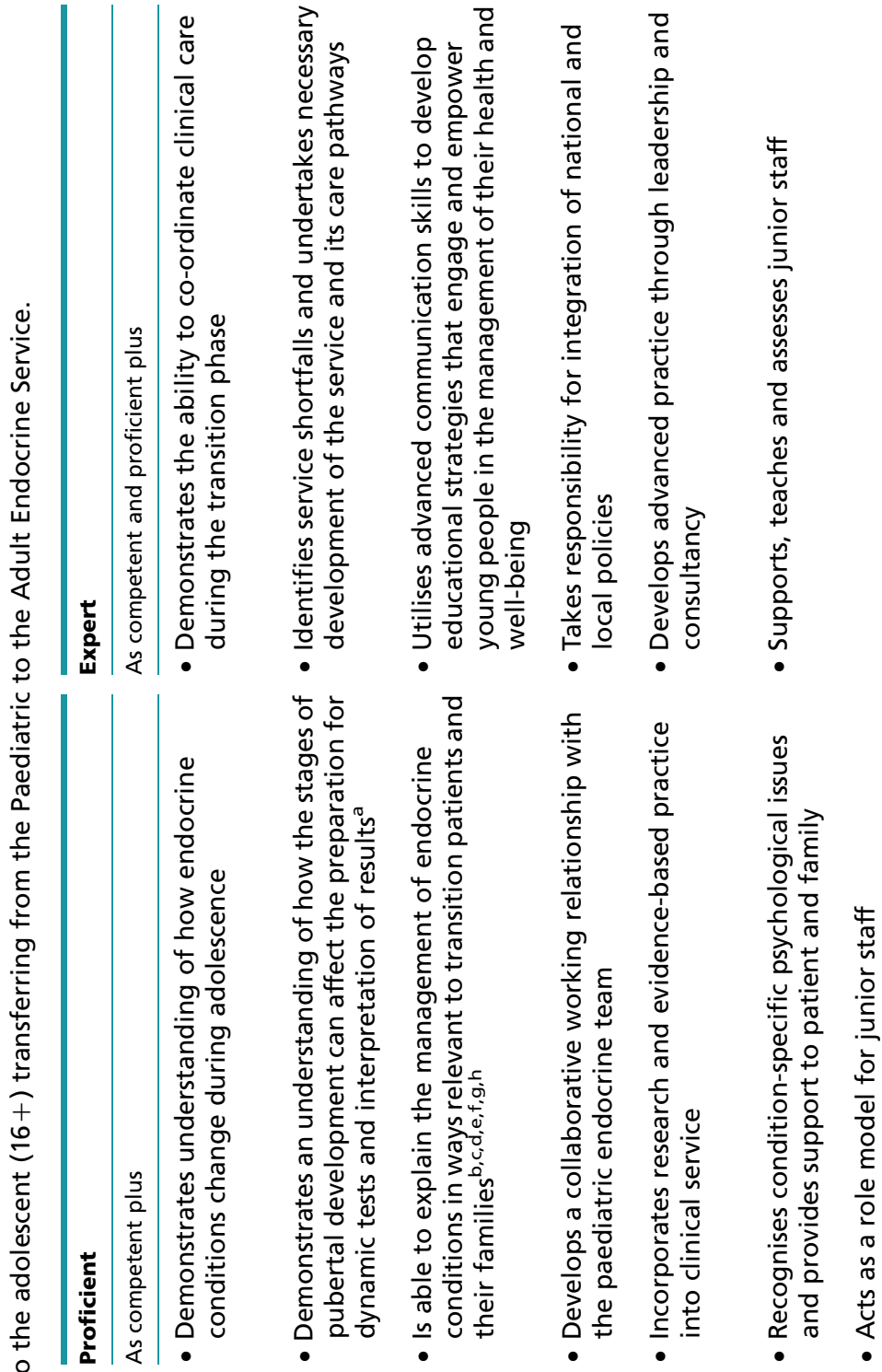

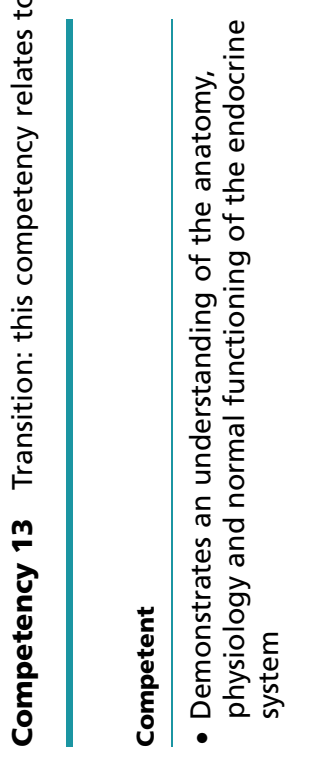

http://www.endocrineconnections.org DOI: 10.1530/EC-14-0134
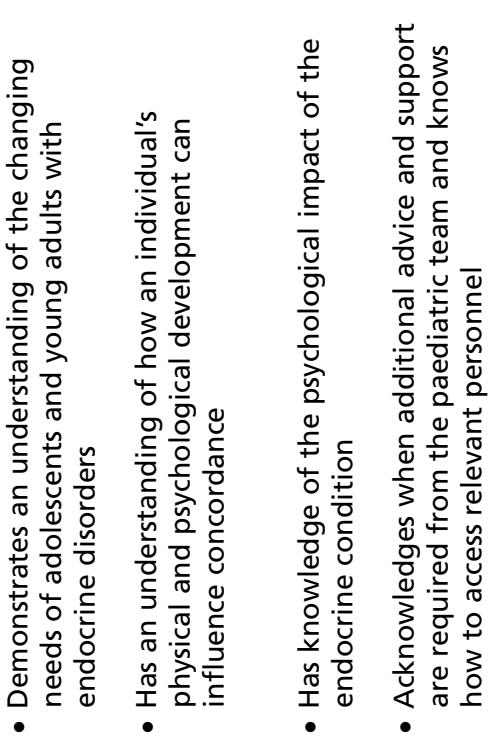

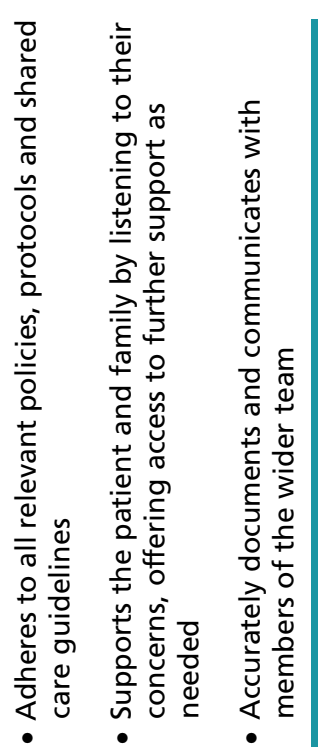

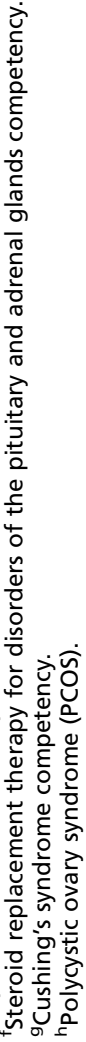

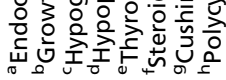




\section{Sources}

The primary source for this document is Competences: an integrated career and competency framework for children's endocrine nurse specialists (11).

\section{Author contribution statement}

V Kieffer, K Davies, C Gibson, M Middleton, J Munday, S Shalet, L Shepherd and $\mathrm{P}$ Yeoh all contributed equally to this work.

\section{Acknowledgements}

The authors would like to thank all those who have supported the development of this Competency Framework. They are grateful for the support of the Society for Endocrinology and the invaluable help provided by Julie Cragg, Tracey Curtis, Rachel Austin and Nicci Komlosy. They are grateful to K Davies, the lead author of the Royal College of Nursing 2008 publication Competencies: An Integrated Career and Competency Framework for Paediatric Endocrine Nurse Specialists (now revised as reference (11)) for her permission to use the document as a basis for these competencies.

\section{Contributors and members of the working group:}

Chair: V Kieffer MA BSC (Hons) RGN Nurse Independent Prescriber, Endocrine Nurse Specialist, Leicester Royal Infirmary.

Members in alphabetical order:

K Davies RN (Child) DipHE BSc (Hons) MSc, Clinical Nurse Specialist in Endocrinology, Great Ormond Street Hospital for Children NHS Trust, London. C Gibson BSC (Hons) RGN Nurse Independent Prescriber, Endocrine Specialist Nurse, Manchester Royal Infirmary.

M Middleton RGN Endocrine Specialist Nurse, Aberdeen Royal Infirmary. J Munday RGN RSCN BSC (Hons) Nurse Independent Prescriber, Lead Nurse Endocrinology, Queen Alexandra Hospital, Portsmouth.

$S$ Shalet BSC (Hons) RN (Adult) MSC PGC Education Nurse Independent Prescriber, Endocrine Specialist Nurse, Salford Royal Hospitals Foundation Trust. L Shepherd MSc BSc (Hons) DipHE RN (Adult) Nurse Independent Prescriber, Endocrinology ANP, Heart of England NHS Foundation Trust.

$P$ Yeoh RGN BSc MSc Nurse Independent Prescriber, Consultant Nurse in Endocrinology, The London Clinic.

\section{Society for Endocrinology legal disclaimer:}

The Society for Endocrinology has the ownership of the copyright of this document. All queries should be directed to Society for Endocrinology 22 Apex Court, Woodlands Bradley Stoke, Bristol BS32 4JT, UK; info@endocrinology.org.

This publication contains information, advice and guidance to help members of the endocrine community. It is intended for use within the UK, but readers are advised that practices may vary in each country, and outside the UK. The information in this publication has been compiled from professional sources, but its accuracy is not guaranteed. Whilst every effort has been made to ensure the Society for Endocrinology provides accurate and expert information and guidance, it is impossible to predict all the circumstances in which it may be used. Accordingly, to the extent permitted by law, the Society for Endocrinology shall not be liable to any person or entity with respect to any loss or damage caused or alleged to be caused directly or indirectly by what is contained in or left out of this information and guidance.

Review

A review will take place 3 years after the date of publication.

\section{References}

1 Roach S. In The Human Act of Caring: A Blueprint for the Health Profession, revised edition. Ottawa, Canada: Canadian Hospital Association Press, 1992.

2 Carraccio C, Wolfsthal SD, Englander R, Ferentz K \& Martin C. Shifting paradigms: from Flexner to competencies. Academic Medicine 200277 361-367. (doi:10.1097/00001888-200205000-00003)

3 Department of Health. In Modernising Nursing Careers: Setting the Direction. London, UK: Department of Health (available at: http:// webarchive.nationalarchives.gov.uk/20130107105354/http://www. dh.gov.uk/prod_consum_dh/groups/dh_digitalassets/@dh/@en/ documents/digitalasset/dh_4138757.pdf), 2006.

4 Society for Endocrinology. In Competency Framework for Adult Endocrine Nursing. Bristol, UK: Society for Endocrinology (available at: http:// www.endocrinology.org/endocrinenurse/docs/CompetencyFramework ForAdultEndocrineNursing.pdf), 2013.

5 Benner P. From novice to expert. American Journal of Nursing 198282 402-407.

6 Benner P. In From Novice to Expert, Commemorative edition. Upper Saddle River, NJ, USA: Prentice Hall, 2001.

7 Benner P. Using the Dreyfus model of skill acquisition to describe and interpret skill acquisition and clinical judgment in nursing practice and education. Bulletin of Science, Technology \& Society 200424 188-199. (doi:10.1177/0270467604265061)

8 UK Central Council for Nursing, Midwifery and Health Visiting. In Code of Professional Conduct. London, UK: UK Central Council for Nursing, Midwifery and Health Visiting (available at: http://www.nmc-uk.org/ Documents/Archived\%20Publications/UKCC\%20Archived\%20 Publications/Code\%20of\%20Professional\%20Conduct\% 20June\%201992.PDF), 1992.

9 Nursing and Midwifery Council. In The Code: Standards of Conduct, Performance and Ethics for Nurses and Midwives. London, UK: Nursing and Midwifery Council (available at: http://www.nmc-uk.org/Documents/Standards/The-code-A4-20100406.pdf), 2008.

10 Royal College of Nursing. In Advanced Nurse Practitioners: An RCN Guide to Advanced Nursing Practice, Advanced Nurse Practitioners and Programme Accreditation. London: RCN (available at: http://www.rcn.org.uk/ _data/assets/pdf_file/0003/146478/003207.pdf), 2012.

11 Royal College of Nursing. In Competences: An Integrated Career and Competency Framework for Children's Endocrine Nurse Specialists. London, UK: Royal College of Nursing (available at: http://www.rcn.org.uk/ __data/assets/pdf_file/0006/544704/003_264.pdf), 2013.

Received in final form 17 December 2014

Accepted 17 December 2014 http://www.endocrineconnections.org DOI: 10.1530/EC-14-0134
() 2015 Society for Endocrinology Published by Bioscientifica Ltd
This work is licensed under a Creative Commons Attribution-NonCommercial-NoDerivs 4.0 International License. 